\title{
REVITALISASI ATMA REKSA: Wujud Integrasi Solidaritas Rasul Awam
}

\author{
Maria Yulita C. Age \\ Sekolah Tinggi Pastoral Atma Reksa Ende \\ Email: cagemariayulita@gmail.com
}

\begin{abstract}
Abstrak
Solidaritas adalah suatu sikap yang dapat dimiliki oleh setiap manusia yang didalamnya saling berkaitan dengan sebuah ungkapan perasaan seseorang atas rasa senasib dan sepenanggungan terhadap apa yang orang lain rasakan maupun kelompok itu sendiri. Solidaritas pun dapat diwujudnyatakan dalam sikap saling melayani rasul awam. Adapun rasul awam yang dimaksudkan dalam tulisan ini adalah para katekis atau guru agama. Artikel ini bertujuan memberikan gambaran tentang upaya menghidupkan kembali "atma reksa" yang berarti jiwa/roh pelayanan atau semangat melayani dalam diri rasul awam sebagai wujud solidaritas di masa pandemic. Konsili Vatikan II dengan tegas dan jelas telah memberikan keluhuran, panggilan, tugas perutusan, dan martabat kaum awam dalam dekrit Kerasulan Awam (Apostolicam Actuositatem). Metode yang digunakan dalam uraian ini adalah metode kepustakaan. Data dianalisis secara induktif dengan cara menguraikan hal-hal yang berkaitan dengan solidaritas kaum awam dalam terang roh pelayanan kemudian menarik kesimpulan atas uraian yang dipaparkan. Adapun hal-hal yang dipaparkan dalam tulisan ini antara lain makna atma reksa, gambaran tentang solidaritas rasul awam, dan wujud solidaritas rasul awam sebagai pendidik, sebagai petugas pastoral di masa pandemik.
\end{abstract}

Kata kunci: revitalisasi; atma reksa; solidaritas; rasul awam

\section{PENDAHULUAN}

Dewasa ini di tengah situasi zaman ini dituntut semangat merasul kaum awam yang tidak kalah besar. Bahkan situasi sekarang ini jelas memerlukan kerasulan yang lebih intensif dan lebih luas. Dalam Gereja terdapat keanekaan pelayanan, tetapi satu dalam tugas perutusan. Para Rasul diserahi tugas oleh Kristus untuk tugas mengajar, menyucikan dan memimpin atas nama dan kuasa-Nya. Sedangkan kaum awam ikut serta mengemban tugas imamat, kenabian dan rajawi Kristus dengan melaksanakan tugas perutusan dalam gereja dan dunia. Dengan kata lain, panggilan kaum awam adalah menjalankan kerasulan dengan kegiatan mereka untuk mewartakan Injil, menjadi saksi Kristus di tengah dunia. Ciri khas kaum awam adalah hidup ditengah-tengah masyarakat dengan urusan-urusan duniawinya, dipanggil oleh Allah untuk menjadi 'garam, terang dan ragi' bagi masyarakat.

Kaum awam menerima tugas dan haknya untuk merasul berdasarkan persatuan mereka dengan Kristus sebagai Kepala berdasarkan babtisan yang mereka terima. Melalui pembabtisan mereka disaturagakan dalam tubuh mistik Kristus, melalui penguatan mereka diteguhkan oleh kekuatan Roh Kristus, dan dengan demikian oleh Tuhan sendiri ditetapkan untuk merasul. Mereka ditakdiskan kedalam martabat imamat rajawi dan bangsa yang kudus (1 Petrus 2: 4-10), untuk melalui segala kegiatan mereka mempersembahkan kurban rohani, dan dimana pun mereka berada memberi kesaksian akan Kristus.

Kerasulan dijalankan dalam iman, harapan dan cinta kasih, yang dicurahkan oleh Roh Kudus dalam hati semua anggota Gereja. Bahkan karena perintah cinta kasih, perintah Tuhan yang utama, segenap umat beriman kristiani didesak untuk mengusahakan kemuliaan Allah. Maka semua orang beriman kristiani mengemban tugas mulia, yakni berjerih payah supaya warta keselamatan ilahi dikenal dan diterima oleh semua orang dimana-mana.

Yesus Kristus mengajarkan kepada para pengikutnya khususnya kaum awam untuk senantiasa merevitalisasi atau mengutamakan atma reksa atau roh pelayanan dalam menjalankan segala aktivitas pelayan baik pelayanan sabda maupun sakramen-sakramen yang secara khas diserahkan kepada para imam. Dalam pelayanan itu, kaum awam pun harus memainkan perannya yang sangat penting, yakni sebagai rekan pekerja demi kebenaran sehingga pelayanan kerasulan awam dan pelayanan pastoral pun saling melengkapi. 
Pandemi ini telah menggarisbawahi kesalingketergantungan antarmanusia, semua terhubung satu sama lain, untuk yang lebih baik atau lebih buruk. Oleh karena itu, agar semua keluar dari krisis ini lebih baik daripada sebelumnya, semua orang perlu melakukan bersama-sama; bersama-sama, bukan sendirian. Bersama-sama. Jangan sendirian, sebab tak ada sesuatu yang bisa dibuat. Entah itu dikerjakan bersamasama, atau sama sekali tidak dikerjakan. Setiap orang harus mengerjakannya bersama-sama, dalam solidaritas.

Kata 'solidaritas' sedikit dipandang usang dan sering salah dimengerti, akan tetapi kata itu mengacu pada sesuatu yang lebih daripada sekadar beberapa tindakan-tindakan kemurahan hati yang sesaat. Akan tetapi solidaritas kaum awam lebih merujuk pada pelayanan kerasulan kaum awam kepada semua umat manusia sebagai mana para rasul mereka pun sebagai murid Kristus yang berperan serta dalam tugas Kristus sebagai imam, nabi, dan raja, kaum awam berperan aktif dalam kehidupan dan kegiatan gereja. Pelayanan ini dilakukan tanpa memandang muka (Yak 2:1) memandang muka berarti memberikan perhatian khusus terhadap orang tertentu karena kekayaan, busana atau kedudukan mereka. Melakukan hal ini salah karena beberapa alasan. Hal ini tidak menyenangkan Allah yang tidak pernah memandang penampilan lahiriah tetapi hati orang (1Sam 16:7). Sikap semacam ini tidak didorong oleh kasih yang murni untuk semua orang (ayat Yak 2:8). Mengagumi kedudukan sosial adalah dosa terhadap hukum kasih. Sikap ini menjadikan kita "hakim dengan pikiran yang jahat" (ayat Yak 2:4); daripada menghormati "Tuhan kita yang mulia" dan menerima orang berdasarkan iman mereka kepada Kristus, kita dengan tidak adil menunjukkan sikap memihak orang kaya atau orang berkedudukan dengan motivasi yang jahat untuk memperoleh keuntungan.

Inilah apa yang dimaksudkan dengan "solidaritas". Hal ini bukan sekadar persoalan membantu orang lain betapapun itu baik dilakukan. Akan tetapi lebih pada bagaimana keikhlasan pengembanan tugas sebagai rasul awam dalam roh pelayanan yang berjiwa kerasulan sejati. Misalnya, rasul awam harus mampu menjadi sumbu yang mengantar kembali umat yang tersesat dan menjauh dari gereja yang dapat dilakukan melalui kegiatan katekese sehingga berkat pelayanan kaum awam, reksa jiwa-jiwa dan juga tata usaha harta milik gereja lebih tepat guna.

\section{REVITALISASI ATMA REKSA: SOLIDARITAS RASUL AWAL AWAM 2.1 Revitalisasi Atma Reksa}

Revitalisasi adalah proses, perbuatan menghidupkan atau menggiatkan kembali. Atma reksa adalah dua kata yang berasal dari bahasa Sansekerta, yakni atma yang artinya jiwa, roh, semangat dan reksa yang berarti melayani. Atma reksa adalah jiwa atau semangat melayani. Yesus menjalankan tugas kegembalaan-Nya dengan prinsip dasar pelayanan yang dipegang yakni pilihan mendahulukan tanpa memandang suku agama atau pun ras (Banawirata, 2002:21). Jadi, sebagai rasul awam seorang katekis harus mampu mengejawartakan panggilan Kristus sebagai pewarta dan pendidik.

Peran para katekis/rasul awam di dunia ini harus disertai cinta kasih akan tugasnya, sehingga gereja membutuhkan katekis-katekis yang berkarakter. Suka cita Injil dapat menjangkau hati orang bila para pewarta bekerja penuh komitmen, siap sedia, dan sabar dalam karya pelayanannya. Tantangan zaman postmodern tidaklah mudah. Di tengah zaman ini, menjadi pelayan memang merupakan salah satu semangat dasar yang kuat dalam seluruh hidup, pengajaran, dan pengabdian Yesus (Sudiharsa, 2006:142). Pewartaan Injil bukan sekedar perkara mengisahkan sejarah keselamatan atau meneruskan informasi tentang ajaran-ajaran gereja melainkan bagaimana kegelisahan dan keseharian orang-orang didengarkan dan dalam keyakinan akan tuntunan Roh, mereka secara perlahan dihantar kepada perjumpaan yang menghidupkan dengan Kristus yang bangkit.

Oleh karena itu, revitalisasi atma reksa merupakan upaya menghidupkan kembali semangat melayani dalam diri rasul awam. Cara menghidupkan kembali semangat pelayanan dapat dijalankan oleh setiap rasul awam baik secara perorangan maupun secara kolektif, sehingga rasul awam pun diajak untuk mengemban tugas yang sama layaknya Kristus di zaman-Nya. Rasul awampun harus bersemangat melayani karena Yesus sendiri bersabda "Aku datang untuk melayani bukan untuk dilayani”. 


\subsection{Solidaritas Rasul Awam}

Gaudium et Spes (GS) menekankan pada solidaritas Gereja pada dunia. Di dalam GS diungkapkan pandangan iman mengenai hidup manusia sebagai makhluk sosial yang hidup dalam masyarakat. Pada dasarnya manusia adalah makhluk sosial dan politik. Disamping itu, GS memandang bahwa karena semakin berkembangnya ketidak adilan, maka diperlukan kerja sama untuk mewujudkan kesejahteraan umum. Kerja sama yang berjalan dengan baik akan mendorong perilaku setia kawan. Oleh karena itu, setiap orang dituntut untuk menjadikan dirinya sebagai sesama bagi yang lain (GS 23 -27). Gereja sebagai sakramen keselamatan hendak menghadirkan keselamatan Allah di tengah dunia. Oleh karena itu, tugas umat beriman adalah mewartakan kabar gembira, tidak hanya kepada dirinya sendiri (internal), melainkan kepada seluruh dunia (eksternal). Kaum awam/rasul awam dituntut menggunakan hak suaranya untuk menyuarakan kebenaran dan memberikan sumbangannya bagi terselenggaranya kesejahteraan umum (GS 30).

Solidaritas adalah suatu sifat (perasaan) solider, sifat satu rasa (senasib), perasaan setia kawan yang terdapat pada suatu kelompok anggota wajib yang memilikinya. Menurut Emile Durkheim (1858) solidaritas merupakan suatu keadaan hubungan antara individu dan kelompok yang dapat didasarkan pada perasaan moral dan kepercayaan yang diikuti bersama dan diperjelas oleh suatu pengalaman emosional bersama. Selanjutnya Robbert M.Z Lawang (1985:262) mengungkapkan bahwa solidaritas adalah dasar pengertian solidaritas sosial tetap kita berpegang yakni kesatuan, persahabatan, saling percaya yang muncul dari tanggung jawab dan kepentingan bersama diantara para anggota.

Jadi, dapat disimpulkan bahwa solidaritas adalah rasa kebersamaan, rasa kesatuan kepentingan, rasa simpati, sebagai salah satu anggota dari kelas yang sama. atau bisa di artikan perasaan atau ungkapan dalam sebuah kelompok yang dibentuk oleh kepentingan bersama.

Solidaritas terdiri atas dua bagian yakni solidaritas mekanik dan solidaritas organik. Solidaritas mekanik menggambarkan sistem komunikasi serta suatu ikatan dalam masyarakat yang mempunyai perasaan yang sama, memiliki sebuah kecenderungan yang sama, masyarakat lebih dapat bisa dikatakan sebagai suatu keseragaman atau homogen, dan jika diantara anggota masyarakat tersebut ada yang menghilang maka dari itu dapat dikatakan tidak lagi memiliki pengaruh yang besar terhadap suatu dampak pada diri sendiri maupun kelompok masyarakat tersebut. Solidaritas rrganik merupakan solidaritas atau kekompakan yang berdasarkan atas sebuah perbedaan, solidaritas organik timbul karena munculnya pembagian kerja yang semakin besar, solidaritas organik berdasarkan atas jenjang ketergantungan yang sangat tinggi.

Solidaritas akan timbul karena adanya perasaan senasib dan seperjuangan, pengungkapan rasa solidaritas sebaiknya dapat diungkapan sesuai dengan porsinya atau tidak diungkapkan atau dijelaskan secara berlebihan, sehingga bentuk dari ungkapan timbal balik itu terjadi ketika diri seseorang ini bisa lewat sebuah ungkapan dalam bentuk suatu usaha seseorang untuk dapat merawat kemajemukan yang ada pada kegiatannya sehari-hari. Rasa senasib sepenanggungan adalah suatu dasar yang timbul karena memunculkan suatu rasa solidaritas dalam diri seseorang untuk diri sendiri maupun kelompok.

Bentuk solidaritas yang dapat dilakukan oleh rasul awam dapat berupa solidaritas perseorangan maupun solidaritas kelompok. Bagi kaum awam terbukalah amat banyak kesempatan untuk melaksanakan kerasulan pewartaan Injil dan pengudusan. Ke-saksian hidup kristiani sendiri beserta amal baik yang dijalankan dengan semangat adikodrati, mempunyai daya-kekuatan untuk menarik orang-orang kepada iman dan kepada Allah. Sebab Tuhan bersabda: "Demikianlah hendaknya terangmu bercahaya di depan orang, supaya mereka melihat perbuatanmu yang baik dan me-muliakan Bapamu yang di surga" (Mat 5:16). Akan tetapi kerasulan semacam itu tidak hanya terdiri dari kesaksian hidup saja. Rasul yang sejati mencari kesempatan-kesempatan untuk mewartakan Kristus dengan kata-kata, baik kepada mereka yang tidak beriman untuk menghantar mereka kepada iman, baik kepada kaum beriman untuk mengajar serta meneguhkan mereka,dan mengajak mereka hidup dengan semangat lebih besar."Sebab cinta kasih Kristus mendesak kita" (2Kor 5:14). Dan di hati semua orang harus menggema kata-kata Rasul: "Celakalah aku, jika aku tidak memberitakan Injil" (1Kor 9:16). Tetapi pada zaman sekarang muncullah masalah-masalah baru, dan beredarlah kesesatan-kesesatan amat gawat, yang berusaha menghancurkan sama sekali agama, 
tata kesusilaan dan masyarakat manusia sendiri. Maka gereja dengan tulus hati mengajak rasul awam, masing-masing menurut bakat pembawaan dan pendidikan pengetahuannya, supaya mereka-menurut maksud Gereja lebih bersungguh-sungguh lagi menjalankan peran mereka dalam menggali dan membela azas-azas kristiani, serta dalam menerapkannya dengan cermat pada soal-soal zaman sekarang.

Tugas sosial dalam dunia juga menjadi tugas kaum awam. Keterlibatan tersebut bukan pertama-tama karena perutusan oleh Gereja tetapi karena tuntutan realitas hidup kaum awam di dunia dan kodrat manusia adalah makhluk soaial yang saling membutuhkan satu sama lain. Sikap sosial yang terungkap dalam kehidupan sehari-hari mestinya menjadi ekspresi nyata dari keutamaan-keutamaan kristiani yang dihayati dan dihidupi orang Kristen. Keutamaan lahir dari iman, lahir dari relasi intens dengan Allah dan itulah yang memberikan perspektif dalam tugas serta keterlibatan nyata dalam hidup sehari-hari. Itulah sebabnya relasi dengan Allah menentukan sikap eksistensial orang Kristen serta tindakan yang akan diambilnya dalam menghadapi situasi hidup nyata.

Oleh karena itu, kalau seseorang mau mendalami keutamaan Kristiani maka perlu memiliki konsep yang jelas tentang siapakah Allah yang diimani dan bagaimana sikap iman itu harus ditempatkan dalam permasalahan nyata masyarakat sebagai wujud solidaritas rasul awam. Yesus Kristus adalah pokok iman Kristiani dan di dalam Dia orang sampai pada Allah dan berjumpa dengan Allah. Ajaran dan perbuatan Yesus memperlihatkan sejumlah pokok penting dan relevan bagi teologi moral sosial. Menurut Rudolf Schnackenburg, sikap Yesus berhadapan dengan problem sosial dapat diuraikan dengan melihat bahwa, Yesus masuk dan menjadi bagian dari realita sosial-Nya. Yesus tidak menjalani kehidupan "fuga mundi" (menyingkir dari dunia ramai dan hidup sebagai petapa). Dalam kehidupan-Nya, Ia menjalani kehidupan seperti umumnya pada masa itu. Yesus menjalankan kehidupan sebagai seorang nabi dan memiliki sikapsikap sosial seturut profesi-Nya itu. Berkaitan dengan pewartaan profetis-Nya, Yesus mengambil posisi yang realistis. Ia menggunakan perumpamaan-perupamaan yang sederhana sehingga ide sentral yang mau disampaikan-Nya mudah dipahami. Bahkan di tengah masyarakat kelompok murid Yesus tidak membentuk semacam"persekutuan" tersendiri yang mengkonserntrasikan hidup pada penyambutan kedatangan kerajaan Allah dengan kesalehan hati, cinta persaudaraan dan kemurnian hidup. Sebaliknya Yesus meminta mereka untuk tetap tinggal di dunia (Yoh 17:15); mengutus mereka ke dunia; meneruskan karya Yesus; mewartakan Injil kepada Israel lalu kepada segala bangsa dan segala makhluk.

Solidaritas merupakan keutamaan kristiani yang erat terkait dengan keutamaan lainnya yakni kasih yang merupakan ciri khas para murid Kristus (Yoh 13:35). Menurut Yohanes Paulus II dalam solidaritas terkandung keutamaan-keutamaan lain selain kasih yakni pengampunan dan rekonsiliasi (perdamaian). Paus menegaskan bahwa iman dan sikap moral adalah satu kesatuan. Salah satu apek penting yang harus juga dikembangkan dalam solidaritas adalah dimensi afektif. Solidaritas akan sungguh diperkaya dengan afeksi rasul awam dalam pelayanan yang solider dan merasa sebagai bagian dari sesamanya sebab solidaritas membantu para rasul awam untuk melihat orang lain bukan sebagai sarana, tetapi sebagai sesama, citra Allah.

Dengan demikian, sebagai rasul awam yang dengan penuh keikhlasan dan secara istimewa berbakti kepada gereja perlu dihargai entah berkeluarga atau tidak, untuk sesaat atau selamanya membaktikan diri dalam semangat melayani. Para imam pun baiknya dengan sukacita dan penuh rasa syukur menyambut pengabdian para rasul awam itu, dan berupaya agar mereka dituntun dengan penuh cinta kasih serta mendapat pembinaan yang berkaitan dengan tugas pelayanan yang akan dijalankan oleh rasul awam.

\section{3 Wujud Integrasi Solidaritas Katekis Sebagai Rasul Awam}

Kata katekis berasal dari kata dasar katechein yang berarti mengomunikasikan, membagikan informasi, atau mengajarkan hal-hal yang berkaitan dengan iman. Kehidupan dan perkembangan Gereja Katolik dapat terus berjalan jika ada kerja sama antara para anggota Gereja baik itu kaum awam maupun kaum Hierarki sebagaimana dikutip dalam Ef 4:5 "satu Tuhan, satu iman dan satu baptisan". Dalam arti bahwa kaum awam maupun Hierarki mempunyai martabat dan tugas perutusan yang sama dalam pewartaan kabar gembira Yesus Kristus di dunia ini. Keterlibatan kaum awam di bidang pewartaan kabar sukacita ini salah satunya dengan menjadi katekis. Dengan kata lain profesi kehidupan seorang katekis 
adalah mengajar, mewartakan Sabda Allah. Kesempatan untuk mewartakan sabda Tuhan bagi kaum awam tidak dilakukan oleh orang-orang tua saja tetapi diharapkan orang muda katolik juga terlibat didalamnya, sehingga perkembangan Gereja semakin hari semakin menunjukkan karya Allah di dunia ini. Oleh karena itu, selalu ada kaderisasi bagi orang muda katolik untuk melaksanakan pewartaan kabar gembira Yesus Kristus.

Upaya menghayati dan menyadari jati dirinya sebagai katekis, maka seorang katekis harus mampu mengembangkan semangat hidup yang dapat dijadikan tolak ukur tugas perutusannya, sebab katekis adalah orang beriman yang dapat menjadi contoh orang beriman lainnya yangmemiliki hidup rohani yang mendalam. Katekis terbuka pada karya Roh serta menyadari panggilan dan perutusannya. Katekis adalah anggota umat yang merupakan pribadi yang sederhana dan rendah hati. Katekis bersemangat melayani karena Yesus sendiri bersabda "Aku datang untuk melayani bukan untuk dilayani". Katekis rela berkorban: waktu, tenaga, kepentingan pribadi, keluarga, harta.

Uraian di atas menegaskan bahwa seorang katekis harus memiliki hidup rohani yang mendalam dengan rajin berdoa, membaca kitab suci, dan berdevosi. Selain itu seorang katekis harus memiliki nama baik sebagai pribadi dan keluarga yang dapat diterima oleh umat serta mempunyai komitmen yang tinggi untuk mewartakan kabar gembira, tidak lupa seorang katekis juga memiliki pendidikan dan ketrampilan yang cukup.

Pelaksanaan tugas perutusan sebagai katekis pastilah memiliki tantangan-tantangan yang menghambat pewartaan dan tantangan itu harus dihadapi, sehingga tugas perutusan dapat berjalan dengan baik. Tantangan tersebut antara lain dari dalam diri sendiri, menyadari akan kelemahan dan kerapuhan diri merupakan hal yang baik, tetapi bukan berarti dengan kelemahan dan kerapuhan tersebut menghambat tugas perutusan yang dipercayakan kepada katekis, dengan harapan bahwa adanya kekuatan dan bantuan Allah semua tugas-tugas dapat berjalan sesuai dengan kehendakNya. Sebagaimana tercantum dalam 2 Kor 4:7 "Tetapi harta ini kami punyai dalam bejana tanah liat, supaya nyata, bahwa kekuatan yang melimpah-limpah itu berasal dari Allah, bukan dari diri kami”.

Kondisi tanah batin pendengar yang berbeda-beda, sehingga dibutuhkan ketekunan dan kesabaran untuk mewartakan sabda Tuhan. Dengan demikian, seorang katekis dituntut untuk mengimani bahwa para pendengar itu adalah kawanan domba milik Kristus sendiri yang mesti diberi santapan firman dan digembalakan. Cinta akan Kristus memotivasi kita untuk menunaikan tanggungjawab. Sebagaimana yang tercantum dalam Yoh 21: 17 "Kata Yesus kepadanya untuk ketiga kalinya: "Simon, anak Yohanes, apakah engkau mengasihani Aku?" Maka sedih hati Petrus karena Yesus berkata untukketiga kalinya: "Apakah engkau mengasihi Aku?" Dan iaberkata kepadaNya: "Tuhan Engkau tahu segala sesuatu, Engkau tahu bahwa aku mengasihi Engkau."Kata Yesus kepadanya: "Gembalakanlahdomba-dombaKu”.

Medan pewartaan yang hadapi tidak selalu mudah, sebab dalam pewartaan Injil seorang katekistidak memilih sendiri "kawanan domba yang gemuk", tetapi bersama yang lain mereka peduli pada kawanan yang dipercayakan. Terkadang seorang katekis sungguh dituntut berkorban, dihadapkan pada aneka kesulitan dan penganiayaan. Sebagai katekis rasul awam tidak ingin seperti benih yang jatuh di tanah berbatu, yang cepat layu karena penindasan dan penganiayaan, namun penderitaan itu justru mematangkan imannya.

\section{Solidaritas Rasul Awam/Katekis Sebagai Pendidik}

Rasul awam atau katekis dapa menunjukan sikap solidaritas dalam wujud sebagai seorang pendidik yang mengambil peranan esensial dalam membantu peserta didik, untuk mengembangkan anak didiknya. Pendidik berupaya menuntun peserta binaan ke arah kedewasaan jasmani dan rohani baik itu lewat pembinaan pribadi, mental dan akhlak anak didiknya. Dalam hal ini guru agama/katekis bukan saja pengajar pengetahuan atau aspek kognitif tetapi proses pendidikan itu menjadi kesempatan membantu anak binaannya dalam proses humanisasi. Dalam semangat pengabdian guru agama/katekis berupaya untuk pembinaan anak didik menjadi pribadi yang utuh, yang menyangkut unsur cipta, rasa dan karsa, kognitif, afektif dan psikomotorik. Dengan ini harus dikatakan bahwa tanggung jawab guru agama/katekis bukan soal teori semata tetapi terutama menyangkut seluruh eksistensi manusia itu. Atas bantuan 
guru agama/katekis, anak binaan dipersiapkan mampu menghadapi realitas sosial dan mampu menghadapi masalah hidup kini dan di masa depan.

Dalam konteks ini profesi sebagai guru agama/katekis itu mulia. Sungguh tampak dan nyata tanggung jawab sosial guru agama/katekis itu dalam pembentukan kematangan pribadi seseorang. Profesi guru agama/katekis itu pun menjadi panggilan untuk perwujudan diri menjadi sesama bagi banyak orang lain. Mengacu pada peran dan tugas guru seperti di atas, mungkin peran guru agama/ katekis itu mengandung pesan khusus lagi bila dibanding dari profesi yang biasa. Dalam profesi guru agama/katekis bukan saja tugas mengajar untuk mengetahui objek bidang studi yang dikuasai tetapi suatu sikap hidup yang mau dihayati atas dasar iman. Peran guru agama/katekis itu sangat terkait dengan misi gereja yang secara tidak langsung memberi perutusan kepada guru agama/katekis dalam kaitan tugasnya sebagai pembina dan pengajar iman.

\section{Solidaritas Rasul Awam/Katekis Sebagai Petugas Pastoral}

Kedudukan rasul awam/katekis harus dibangun dan didasarkan atas keyakinan mendasar yaitu panggilan kemuridan. Katekis itu dipanggil mengemban perintah Yesus Kristus untuk mewartakan pesan keselamatan Allah bagi semua orang. Yesus sendiri memberi suatu contoh konkret dalam hidup-Nya. Dia mengemban kehendak Bapa dan atas dasar itu Dia memberi tugas perutusan kepada Gereja "Pergilah ke seluruh dunia, beritakanlah Injil kepada segala makhluk" (Mrk 16:15). Kemudian mendekati murid-Nya lalu berkata, "Kepada-Ku telah diberikan segala kuasa di surga dan di bumi, jadikanlah bangsa jadi murid-Ku...." (Mat. 28:18-19). Saat Yesus naik ke surga Dia berkata kepada murid-Nya, "dan kamu adalah saksi-Ku hingga akhir dunia dan ujung bumi" (Kis 1:8). Peran utama dan pertama dari pengajaiman itu adalah menyadari dirinya sebagai orang yang diutus. Evangelium Nuntiandi mengatakan bahwa kalau orang mempermaklumkan Injil keselamatan, mereka harus melakukan hal itu atas perintah dan dengan rahmat Kristus (EN. 59).

Dalam hal ini rasul awam/katekis harus belajar dari Sang Guru yaitu Kristus sendiri yang dengan tegas mengaku bahwa Diapun adalah yang diutus (Yoh 5:30). Yesus mengutus para murid mewartakan kabar gembira dan kebaikan Tuhan bagi mereka yang dijumpai. Menempatkan diri sebagai utusan atas otoritas Pengutus Agung sungguh mencipta perasaan yang memberi kegairahan dalam diri katekis yang pada akhirnya dapat menghantar mereka pada pengakuan bahwa mereka murid dan saksi. Dengan ini, maka para katekis bukan melulu pengajar doktrin/dogma gereja, tetapi lebih tepatnya adalah untuk menangkap hati dan pikiran umat manusia secara umum dan anak binaannya secara khusus sehingga pada akhirnya mempersatukan setiap orang dalam semangat Koinonia dan agar mengalami dan memahami ajaran iman dan menghidupi Injil Tuhan. Dalam hal ini fungsi katekis dari guru agama/katekis itu mengalir dari perintah semangat misioner Yesus Kristus.

Wujud solidaritas rasul awam dalam perannya sebagai petugas pastoral mewartakan dan memperkenalkan belas kasih Allah kepada umat manusia dan anak didik secara khusus tentang Kabar Gembira. Dalam mengemban tugas perutusan ini tentu katekis itu melampaui peran guru biasa dan pendidik lainnya. Dalam tugas guru itu tersirat aspek misi dan perutusan sebagai pelayan yang senantiasa melayani dengan senantiasa memaknai atma reksa dalam perutusannya.

\section{Wujud Solidaritas Rasul Awam di Masa Pandemi Covid-19}

Solidaritas rasul awam di masa pandemi sangat dibutuhkan, sebab jarak sosial atau pembatasan sosial membuat orang tidak dapat dengan leluasa melakukan segala aktivitas. Pelayanan yang berhubungan dengan keagaman dan segala aspek kehidupan pun dilaksanakan dari rumah dengan protokol kesehatan. Solidaritas yang dimaksudkan tidak hanya mengarah pada solidaritas kepada masyarakat pada umumnya tetapi juga mengarah pada semangat pelayanan dalam lembaga pendidikan. Rasul awam tidak hanya menjalankan solidaritas pelayanan dalam bidang pastoral gereja melainkan juga pada bidang pastoral sekolah. Dalam hal ini rasul awam sangat dibutuhkan demi terlaksananya tugas

perutusan Kristus sebagai guru. Rasul awam yang berprofesi sebagai pendidik pun dituntut memiliki solidaritas pelayanan yang total sebab pelaksanaan pembelajaran berbeda dengan sebelumnya. Interaksi 
guru-siswa dalam proses pembelajaran terhambat meskipun hal ini sangat penting untuk mengetahui kemajuan proses belajar siswa.

Proses belajar daring, menuntut rasul awam/katekis harus benar-benar memperhatikan cara belajar siswa yang dilakukan secara daring. Peran katekis kini sangatlah penting mengingat proses belajar sudah tidak bisa bertatap muka lagi. Para katekis harus benar-benar berupaya semaksimal mungkin agar peserta didiknya dapat memahami materi yang disampaikan secara daring. Oleh karena itu, di tengah maraknya wabah virus corona ini, beberapa peran rasul awam yang tugas perutusannya melaksanakan tugas sebagai guru atau pendidik harus mampu menjadi motivator, innovator, dan evaluator yang baik agar aspek kognitif, afektif, dan psikomotorik peserta didik dapat dibentuk dengan baik, sebab situasi sekarang menyebabkan stress pada peserta didik akibat tugas yang diterima tanpa penjelasan yang baik oleh pendidik. Motivator yang baik hendaknya tetap memberikan pelayanan pengajaran yang total bukan semata-mata hanya dengan memberikan tugas secara terus menerus.

Wujud solidaritas rasul awam di masa pandemi ini dalam pelaksanannya berbeda-beda di setiap daerah. Misalkan di daerah perkotaan dengan fasilitas dan jaringan yang memadai membuat pembelajaran daring berjalan dengan baik. Namun di daerah pedesaan pembelajaran semacam ini tidak dapat dilakukan karena situasi dan kondisi teknologi maupun perekonomian yang tidak sama. Jika, diamati para rasul awam di pedesaan tetap menjalankan aktivitas pembelajaran dari rumah ke rumah. Mereka dengan semangat pelayanan yang tulus dan sukacita tetap menuntun anak didiknya meski harus menempuh jarak yang jauh sebab jarak tempat tinggal peserta didik yang berbeda. Mereka dengan jiwa yang besar rela melakukan segalanya, mengorbankan keluarga dan aktivitas lainnya demi pelayanan. Akan tetapi, atma reksa yang tertanam dalam diri rasul awam ini membangkitkan semangat melayani yang sejati.

Oleh karena itu, kepada setiap rasul awam, Tuhan menyerukan dengan sangat supaya mereka dengan sukareka dengan jiwa besar, dengan hati yang siap-sedia menanggapi sapaan Kristus yang justru sekarang ini lebih mendesak mengundang para rasul awam dan supaya rasul awam mengikuti dorongan Roh Kudus.

\section{PENUTUP}

Revitalisasi atma reksa mengajak para wasul awam semakin memaknai panggilan kerasulannya. Rasul awam dapat menjalankan kerasulan mereka secara perorangan atau tergabung dalam berbagai paguyuban atau perserikatan. Kerasulan, yang harus dijalankan oleh setiap orang secara pribadi dan secara melimpah mengalir dari sumber hidup kristiani yang sejati (lih. Yoh 4:14), merupakan landasan dan syarat bagi semua kerasulan awam, juga yang bersifat kolektif, dan tidak dapat digantikan oleh apa pun juga. Semua awam dalam keadaan mana pun juga dipanggil dan wajib menjalankan kerasulan. Kerasulan itu selalu dan di mana-mana memang berharga, tetapi dalam situasi-situasi tertentu merupakan satu-satunya yang sesuai dan mungkin. Banyak wujud solidaritas kaum awam atau dapat dikatakan terdapat banyak bentuk kerasulan, yang bagi kaum awam merupakan jalan untuk membangun Gereja dan memaknai semangat solidaritas Yesus di tengah situasi dunia yang kurang bersahabat entah sebagai pendidik atau petugas pastoral.

Solidaritas rasul awam akan timbul karena adanya perasaan senasib dan seperjuangan, pengungkapan rasa solidaritas sebaiknya dapat diungkapan sesuai dengan porsinya atau tidak diungkapkan atau dijelaskan secara berlebihan, sehingga bentuk dari ungkapan timbal balik itu terjadi ketika diri seseorang ini bisa lewat sebuah ungkapan dalam bentuk suatu usaha seseorang untuk dapat merawat kemajemukan yang ada pada kegiatannya sehari-hari. Rasa senasib sepenanggungan adalah suatu dasar yang timbul karena memunculkan suatu rasa solidaritas dalam diri seseorang untuk diri sendiri maupun kelompok.

Akhirnya hendaklah para rasul awam menjiwai hidup mereka dengan cintakasih, dan sejauh mampu mengungkapkannya dengan tindakan nyata. Mereka diajak untuk melalui bermacam-macam bentuk dan cara dalam satu kerasulan Gereja, yang tiada hentinya harus disesuaikan dengan kebutuhan-kebutuhan zaman yang baru, membawakan diri sebagai rekan-rekan sekerja-Nya, selalu giat dalam karya Tuhan, karena menyadari bahwa jerih-payah mereka tidak sia-sia dalam Tuhan (lih. 1Kor 15:58), sebab Yesus Kristus bersabda Aku datang untuk melayani bukan untuk dilayani. 


\section{REFERENSI}

Dokumen Konsili Vatikan II terj. R. Hardawiryana, "Dekrit Tentang Kerasulan Awam (Apostolicam Actuositatem). 2017. Jakarta: Penerbit Obor

Gaudium Et Spes (Kristus Tuhan). 2017. Jakarta: Konferensi Waligereja Indonesia (KWI), Departemen Dokumentasi dan Penerangan

https://www.dosenpendidikan.co.id/solidaritas-adalah/ diakses tanggal 20 Februari 2021

Jurnal Atma Reksa, Jurnal Pastoral dan Kateketik, Vol.1 Edisi Januari-Juli 2016. Ende: STIPAR

Johanes Paulus II, Sollicitudo Rei Sosialis, terjemahan Bahasa Indonesia oleh Marcel Beding. 1987. Ende: Nusa Indah

Badan Pengembangan dan Pembinaan Bahasa. Kamus Besar Bahasa Indonesia. Jakarta: CV Adi Perkasa. 2018

Rudolf Schnackenburg, Perjanjian Baru Sebagai Pembina Akhlak Umat Kristen, (Terj. Cletus Groenen OFM), Nusa Indah 1971

Sudiharsa, Raymundus. 2006. Iman dan Budaya DAlam Agenda Misi Gereja, Dalam Komisi Teologi KWI, Dialog Iman dan Budaya. Yokyakarta: Yayasan Pustaka Nusatama 